\title{
Measuring Safeguards Culture
}

\author{
SL Frazar \\ SV Mladineo
}

July 2011

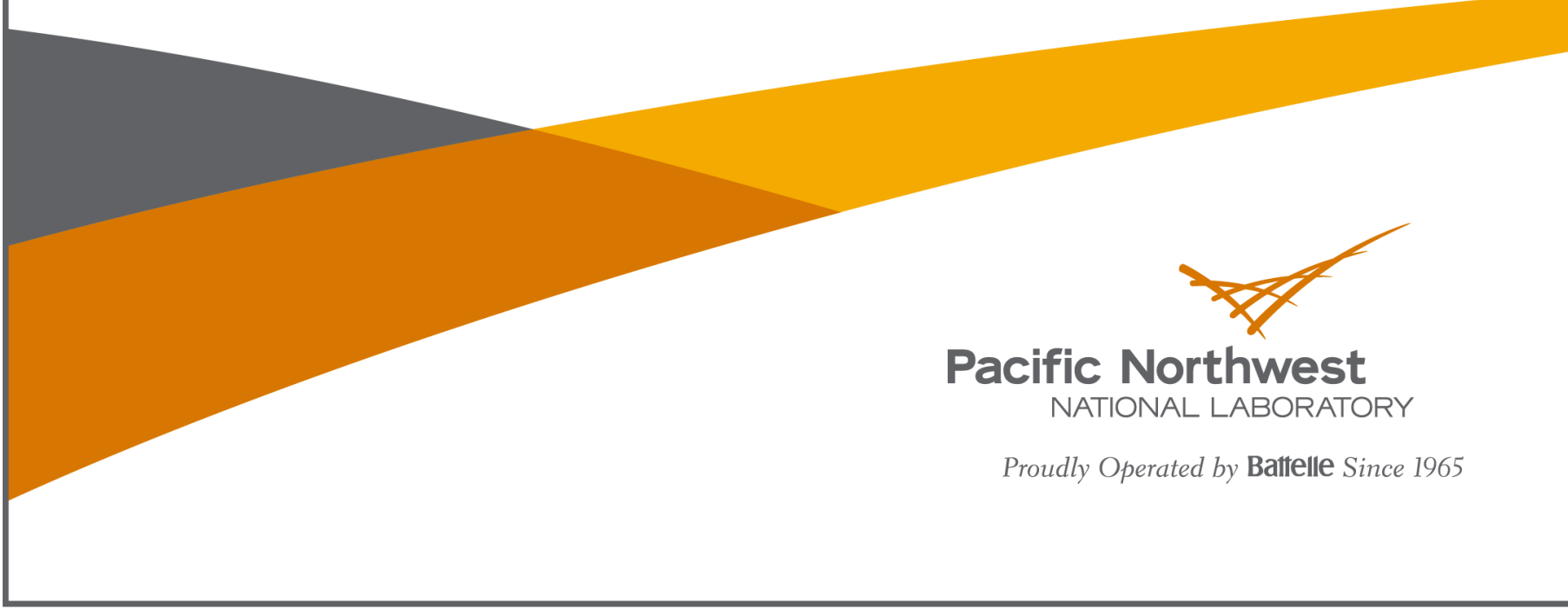




\title{
DISCLAIMER
}

This report was prepared as an account of work sponsored by an agency of the United States Government. Neither the United States Government nor any agency thereof, nor Battelle Memorial Institute, nor any of their employees, makes any warranty, express or implied, or assumes any legal liability or responsibility for the accuracy, completeness, or usefulness of any information, apparatus, product, or process disclosed, or represents that its use would not infringe privately owned rights. Reference herein to any specific commercial product, process, or service by trade name, trademark, manufacturer, or otherwise does not necessarily constitute or imply its endorsement, recommendation, or favoring by the United States Government or any agency thereof, or Battelle Memorial Institute. The views and opinions of authors expressed herein do not necessarily state or reflect those of the United States Government or any agency thereof.

\author{
PACIFIC NORTHWEST NATIONAL LABORATORY \\ operated by \\ BATTELLE \\ for the \\ UNITED STATES DEPARTMENT OF ENERGY \\ under Contract DE-AC05-76RL01830 \\ Printed in the United States of America \\ Available to DOE and DOE contractors from the \\ Office of Scientific and Technical Information, \\ P.O. Box 62, Oak Ridge, TN 37831-0062; \\ ph: (865) 576-8401 \\ fax: $(865) 576-5728$ \\ email: reports@adonis.osti.gov
}

Available to the public from the National Technical Information Service

5301 Shawnee Rd., Alexandria, VA 22312 ph: (800) 553-NTIS (6847)

email: orders@ntis.gov <http://www.ntis.gov/about/form.aspx>

Online ordering: http://www.ntis.gov

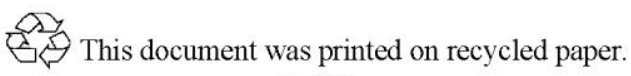

(8/2010) 


\title{
Measuring Safeguards Culture
}

\author{
SL Frazar \\ SV Mladineo
}

July 2011

Prepared for

the U.S. Department of Energy

under Contract DE-AC05-76RL01830

Pacific Northwest National Laboratory

Richland, Washington 99352 



\begin{abstract}
As the International Atomic Energy Agency (IAEA)'s State Level approach to safeguards implementation is holistic and investigatory in nature, creating a need for transparent, nondiscriminatory judgments about a state's nuclear activities. In support of this need, the authors previously explored the value of defining and measuring a state's safeguards culture. We argued that a clear definition of safeguards culture and an accompanying set of metrics could be applied to provide an objective evaluation and demonstration of a country's nonproliferation posture. As part of this research, we outlined four high-level metrics that could be used to evaluate a state's safeguards culture. We identified general data points. This paper elaborates on those metrics, further refining the data points to generate a measurable scale of safeguards cultures. We believe that this work could advance the IAEA's goals of implementing a safeguards system that is fully information driven, while strengthening confidence in its safeguards conclusions.
\end{abstract}

\title{
INTRODUCTION
}

With the development of the Additional Protocol (AP), the International Atomic Energy Agency (IAEA) accelerated its evolutionary process away from a facility-based safeguards approach toward a State-Level Approach. This evolution was triggered by the revelation that Iraq, a state whose nuclear program was under IAEA safeguards, was pursuing undeclared activities that could eventually lead to a nuclear weapon. That revelation made clear that traditional safeguards as implemented under a Comprehensive Safeguards Agreement (CSA) were not adequate to deter a state from pursuing a nuclear weapons program. The IAEA and the international community needed tools and methods that would fill their gaps in knowledge and give them a more complete picture of the nuclear activities underway in each State.

To help fill its gaps in knowledge, the IAEA pursued two major paths: a technical path and a political path. The technical path consisted of a suite of field trials that tested different methods for using environmental samples to detect undeclared activities. Those trials culminated in approval to expand approved safeguards measures for detecting undeclared activities to include the use of environmental swipe samples. The political path consisted of the development of the Additional Protocol (AP), which not only strengthened existing legal authorities, but also expanded the IAEA's access to State nuclear programs and the amount and type of information it has at its disposal to make safeguards conclusions. Today, for States with a CSA in place and an AP in force, the IAEA can conduct an evaluation of the State as a whole, providing greater assurance that nuclear materials have not been diverted from peaceful purposes and that there are no undeclared activities in the State.

In an effort to strengthen its evaluations and conclusions, there has been some debate as to whether the IAEA should take into consideration a State's safeguards culture. This is a difficult and controversial issue for several reasons. First, no official definition for safeguards culture exists and there is little agreement as to how the concept could be evaluated objectively or quantifiably. Those who invoke the concept may have little understanding of its scope or impact on safeguards and struggle to explain why States or the IAEA should care about it. Second, beliefs and intentions are intrinsic features of one'sculture, and it is arguably impossible to measure someone's beliefs and intentions in a quantifiable way. However, it may be possible to measure "artifacts" such as actions and statements that could help an analyst make inferences about a State's beliefs and intentions. This is the premise of Edgar Schein's model, in which he depicts an organization's beliefs as the foundation, its statements about itself in the middle, and its actions -- what can be measured -- at the 
top.' Third, when attempting to develop a set of safeguards culture metrics, it is difficult to differentiate between metrics that measure a state's safeguards compliance and metrics that measure the existence of a safeguards culture. It is our hypothesis that the differentiator resides in the link between the artifact being measured and the entity's mission. That is, when states and facilities perform voluntary activities regarding safeguards because such activities are seen to enhance the mission, this is evidence of a positive safeguards culture. The absence of voluntary actions suggests a weak safeguards culture exists.

This paper contributes to the ongoing debate about the value of integrating safeguards culture into State- level evaluations by building on previous work and refining previously proposed measures and metrics to generate a scale with which safeguards cultures could be measured and compared. We believe this work could advance the State Level Approach being implemented by the IAEA while strengthening confidence in IAEA conclusions and facilitating the prioritization of verification activities.

\section{APPROACH}

There are two reasons to consider safeguards culture as a component of State-level evaluations.

1) A weak safeguards culture could signal that a State is ill-equipped in some way to fully support IAEA safeguards. This is an important issue to address, since resource issues can translate to an increased burden on both the IAEA and the State to resolve discrepancies or anomalies that arise during inspections.

2) The ability to identify, measure, and evaluate safeguards culture could enable assistance providers to work with States on specific areas before anomalies or discrepancies arise. Such intervention would serve as a preventive measure, augmenting current practices to ensure States are meeting international standards and possibly saving valuable resources that otherwise would need to be spent later on resolving issues.

If there is value in integrating safeguards culture into a State-level evaluation, there is a need to establish an agreed-upon definition of safeguards culture. We propose the following definition: " $A$ shared belief among individuals, organizations, and institutions that strict attention to international safeguards requirements and affirmative cooperation with safeguards authorities will enhance their nonproliferation stature and benefit their missions. "ii The metrics described below are intended to measure the artifacts

of safeguards culture. We specifically listed as potential metrics actions that are conducted voluntarily to improve performance in support of a mission. It is our hypothesis that these voluntary safeguardsrelated actions indicate the existence of a positive safeguards culture.

To elaborate further, some actions are performed to meet international requirements or fulfill national regulations. These actions are important for demonstrating transparency and compliance with international obligations, and fundamentally, that is all that is needed to meet international obligations. However, these actions are not necessarily indicators of a strong safeguards culture without evidence that the action is being performed voluntarily and with the intention to safeguard nuclear material and information. Actions that are performed voluntarily reflect possession of the necessary knowledge, skills and abilities; a sense of self-efficacy; beliefs about the balance between the benefits and costs of 
the action; and values that place a priority on the outcome that results from the action. In short, it is the voluntary actions that demonstrate that regulatory compliance is important, and consequently performed completely, effectively, and correctly.

It is worth noting that to fully measure the strength of a State's safeguards culture, we must also examine the systems and structures to see the extent to which they support and reinforce or obstruct and discourage the desired beliefs and behaviors. As David Nadler and Michael Tushman state in their book Competing by Design: The Power of Organizational Architecture, “...the greater degree of congruence, or fit, among the various components, the more effective the organization will be. Put another way, the degree to

which the strategy, work, people, structure, and culture are smoothly aligned will determine the organization's ability to compete and succeed." "iii It is insufficient to examine only the actions taken by staff to perform their jobs better. It is also important to consider whether there are incentives in place to reward and encourage similar actions in the future and to discourage actions that would weaken or jeopardize safeguards performance. The incentive structure is one of the key elements that institutionalize voluntary actions, thereby giving the concept of safeguards culture the tangibility it needs to serve as an indicator of proliferation potential.

The following set of metrics is not intended to be comprehensive but is designed to suggest an approach for measuring safeguards culture. This is similar in concept to the "safety culture ladder" or the "safety maturity model" developed by the international oil and gas industry. ${ }^{\text {iv }}$ We assign values of 1-4 to the metrics, where 1, 2 and 3 indicate compliance-based actions that are performed to obtain a desired outcome. 1 is the least compliant and 3 is the most compliant with requirements. We assign a 4 to voluntary performance-based actions, which, when performed, indicate desire to obtain the specific outcome while meeting best practices or high international standards. When applying these metrics to a country, an analyst could tally the scores and generate an average score. An average rating above 3 would indicate that the state received a preponderance of $4 \mathrm{~s}$, where available, indicating that the state goes beyond simple requirements and takes additional voluntary actions. Such a score would provide evidence of a positive safeguards culture in the State.

\section{NEXT STEPS}

We welcome feedback on our methodological approach and suggestions for additional metrics that would be consistent with a positive safeguards culture. Additional research is required to apply these metrics to actual States to attempt to validate our approach.

\section{CONCLUSION}

We have proposed a set of metrics that reflect the cumulative judgment of the two authors. We recognize that additional metrics are likely to be available that would improve the validity of the approach. We are convinced however, that the approach to measuring the robustness of a State's safeguards culture can be an additional useful tool in the development of a Broad Conclusion in the State Level Approach of a fully information driven safeguards approach. 


\section{METRICS}

\begin{tabular}{|c|c|c|}
\hline $\begin{array}{l}\text { Measure - } \\
\text { The Desired Outcome }\end{array}$ & $\begin{array}{l}\text { Safeguards Metrics - } \\
\text { Actions that demonstrate fulfillment of safeguards requirements and voluntary actions that } \\
\text { demonstrate commitment. }\end{array}$ & Score \\
\hline \multicolumn{2}{|c|}{ The State exhibits international best practices and safeguards norms, conventions, treaties, protocols and resolutions } & $\begin{array}{l}\text { Avg. } \\
\text { Score }\end{array}$ \\
\hline $\begin{array}{l}\text { Is a Party to the Treaty on } \\
\text { the Nonproliferation of } \\
\text { Nuclear Weapons. }\end{array}$ & $\begin{array}{l}\text { State is not a party to the NPT } \\
\text { State is a party to the NPT but is not in good standing. } \\
\text { State is a party to the NPT and is in good standing. }\end{array}$ & $\begin{array}{l}1 \\
2 \\
3\end{array}$ \\
\hline $\begin{array}{l}\text { Implements a Safeguards } \\
\text { Agreement with the IAEA }\end{array}$ & $\begin{array}{l}\text { Lacks a safeguards agreement with the IAEA. } \\
\text { Signed a safeguards agreement } \\
\text { A safeguards agreement is in force }\end{array}$ & $\begin{array}{l}1 \\
2 \\
3\end{array}$ \\
\hline $\begin{array}{l}\text { Implements an Additional } \\
\text { Protocol (AP). }\end{array}$ & $\begin{array}{l}\text { Has not signed the AP. } \\
\text { Implementing the AP on a provisional basis } \\
\text { Ratified the AP. } \\
\text { Performance Based (PB) Action: Conducts outreach to industry and universities to proactively } \\
\text { collect information for its AP declaration. }\end{array}$ & $\begin{array}{l}1 \\
2 \\
3 \\
4\end{array}$ \\
\hline $\begin{array}{l}\text { Complies with safeguards } \\
\text { obligations outlined in } \\
\text { UNSCR } 1540 .\end{array}$ & $\begin{array}{l}\text { Is delinquent in } 1540 \text { reporting. } \\
\text { Initial } 1540 \text { report was submitted } \\
\text { Submits subsequent but incomplete } 1540 \text { reports responsive to } 1540 \text { committee requests. } \\
\text { PB Action: } \mathbf{1 5 4 0} \text { reports are regularly updated with complete information. }\end{array}$ & $\begin{array}{l}1 \\
2 \\
3 \\
4\end{array}$ \\
\hline \multicolumn{3}{|c|}{$\begin{array}{l}\text { The State has an effective legal, regulatory, human and private sector infrastructure capable of supporting safeguards } \\
\text { implementation. }\end{array}$} \\
\hline $\begin{array}{l}\text { National law establishes an } \\
\text { SSAC and independent } \\
\text { regulatory body (SRA) }\end{array}$ & $\begin{array}{l}\text { State lacks an SSAC/SRA } \\
\text { State established either an SSAC or an SRA } \\
\text { State established both an SSAC and an SRA } \\
\text { PB Action: SRA is independent from organizations responsible for promoting nuclear power. }\end{array}$ & $\begin{array}{l}1 \\
2 \\
3 \\
4\end{array}$ \\
\hline SSAC/SRA have authority & SSAC/SRA lack authority concerning safeguards & 1 \\
\hline
\end{tabular}




\begin{tabular}{|c|c|c|}
\hline to implement safeguards & $\begin{array}{l}\text { SSAC/SRA have limited authority concerning safeguards } \\
\text { SSAC/SRA have extensive authority concerning safeguards }\end{array}$ & $\begin{array}{l}2 \\
3\end{array}$ \\
\hline $\begin{array}{l}\text { SSAC/SRA conducts } \\
\text { inspections to implement } \\
\text { safeguards and takes steps } \\
\text { to resolve questions and } \\
\text { inconsistencies generated } \\
\text { during inspections. }\end{array}$ & $\begin{array}{l}\text { SSAC/SRA does not conduct inspections } \\
\text { SSAC/SRA accompanies and supports IAEA inspectors but does not conduct independent inspections. } \\
\text { SSAC/SRA conducts independent inspections and consistency enforces national regulations in support of } \\
\text { national and international safeguards.. } \\
\text { PB Action: State and facilities perform regular self-assessments to identify and resolve issues and } \\
\text { inconsistencies before the official inspection. }\end{array}$ & $\begin{array}{l}1 \\
2 \\
3 \\
4\end{array}$ \\
\hline $\begin{array}{l}\text { SSAC has adequate staff to } \\
\text { conduct its safeguards } \\
\text { functions }\end{array}$ & $\begin{array}{l}\text { SSAC is staffed at } 50 \% \text { or less of required numbers. } \\
\text { SSAC is staffed at } 51-99 \% \text { of required numbers. } \\
\text { SSAC is staffed at } 100 \% \text { of required numbers. } \\
\text { Performance Based Action: SSAC/SRA have an active staff development and recruitment program } \\
\text { to ensure staff skills remain up-to-date and new staff are added to fill vacant positions. }\end{array}$ & $\begin{array}{l}1 \\
2 \\
3 \\
4\end{array}$ \\
\hline $\begin{array}{l}\text { SSAC has adequate } \\
\text { funding to perform its } \\
\text { safeguards functions. }\end{array}$ & $\begin{array}{l}\text { SSAC has 50\% or less of its required funding } \\
\text { SSAC has 51-99\% of its required funding } \\
\text { SSAC has } 100 \% \text { of its required funding } \\
\text { Performance Based Action: SSAC/SRA has a comprehensive financial plan that is regularly } \\
\text { updated to ensure the SSAC remains fully funded at all times. }\end{array}$ & $\begin{array}{l}1 \\
2 \\
3 \\
4\end{array}$ \\
\hline $\begin{array}{l}\text { SSAC has political support } \\
\text { from national authorities }\end{array}$ & $\begin{array}{l}\text { State does not provide political support for its SSAC. }{ }^{\text {vvi }} \\
\text { State provides political support for the SSAC via oral, public statements but statements are not } \\
\text { complemented by actions. }{ }^{\text {vii }} \text {. } \\
\text { State provides political support for the SSAC via public statements and actions. }\end{array}$ & $\begin{array}{l}2 \\
3\end{array}$ \\
\hline $\begin{array}{l}\text { The State has a regulatory } \\
\text { structure for conducting } \\
\text { nuclear material control } \\
\text { and accounting measures. }\end{array}$ & $\begin{array}{l}\text { Some regulations for nuclear material control and accounting measures exist but they are not part of a } \\
\text { well defined structure of elements } \\
\text { A complete regulatory structure exists but is not fully populated } \\
\text { The State has a complete regulatory structure that is fully populated, and frequently revised and updated. }\end{array}$ & $\begin{array}{l}2 \\
3\end{array}$ \\
\hline $\begin{array}{l}\text { Regulatory documents } \\
\text { contain enforcement } \\
\text { mechanisms and are }\end{array}$ & $\begin{array}{l}\text { Regulations do not contain enforcement mechanisms. } \\
\text { Regulations contain enforcement mechanisms but regulatory authority does not perform such } \\
\text { mechanisms. }\end{array}$ & $\begin{array}{l}1 \\
2 \\
3\end{array}$ \\
\hline
\end{tabular}




\begin{tabular}{|c|c|c|}
\hline enforced. & Regulations are enforced through issuance of fines, revocation of licenses etc. & \\
\hline $\begin{array}{l}\text { Inspection findings are } \\
\text { tracked, corrected and } \\
\text { available for review }\end{array}$ & $\begin{array}{l}\text { Findings are tracked } \\
\text { Findings are tracked and reviewed for accuracy } \\
\text { Findings are independently audited (by IAEA). }\end{array}$ & $\begin{array}{l}1 \\
2 \\
3\end{array}$ \\
\hline $\begin{array}{l}\text { State has a human resource } \\
\text { development plan with a } \\
\text { specific section dedicated } \\
\text { to safeguards professionals } \\
\text { (all facilities addressed } \\
\text { under this plan). }\end{array}$ & $\begin{array}{l}\text { Nuclear facilities and regulator hire staff without adequate skills or training to fulfill safeguards mission. } \\
\text { Nuclear facilities/regulator hire expatriots to fulfill safeguards positions. } \\
\text { Nuclear facilities and regulator hire indigenous staff with adequate skills to fulfill safeguards mission at } \\
\text { the plant or organization. } \\
\text { PB Action: Facility/regulator have workforce development plans that address the hiring of } \\
\text { safeguards staff; there is a clear methodology for hiring specific safeguards staff that addresses } \\
\text { staff qualification, evaluation and training. }\end{array}$ & $\begin{array}{l}2 \\
3 \\
4\end{array}$ \\
\hline $\begin{array}{l}\text { There are safeguards } \\
\text { education and training } \\
(\mathrm{E \& T}) \text { programs. }\end{array}$ & $\begin{array}{l}\text { Students are not enrolled in E\&T programs or no E\&T programs exist. } \\
\text { Students are enrolled in E\&T programs } \\
\text { Students enrolled in E\&T programs are hired by government and/or industry } \\
\text { PB Action: Government and industry invest in E\&T programs to train new staff in safeguards } \\
\text { functions; government and industry are seen as long-term career options by students in these } \\
\text { programs. }\end{array}$ & $\begin{array}{l}1 \\
2 \\
3 \\
4\end{array}$ \\
\hline $\begin{array}{l}\text { Country has invested in } \\
\text { safeguards technology } \\
\text { research and development } \\
\text { (R\&D) programs. }\end{array}$ & $\begin{array}{l}\text { The existing technology R\&D programs in the state do not focus on safeguards. } \\
\text { There is only } 1 \text { organization in the state that conducts research specifically into safeguards-related } \\
\text { technologies. } \\
\text { There are more than } 2 \text { organizations in the state that conduct safeguards R\&D programs. } \\
\text { PB Action: The government and industry invest specifically in safeguards-related R\&D programs. }\end{array}$ & $\begin{array}{l}1 \\
2\end{array}$ \\
\hline $\begin{array}{l}\text { There is a program for } \\
\text { passing on safeguards } \\
\text { knowledge to new } \\
\text { safeguards professionals. }\end{array}$ & $\begin{array}{l}\text { No knowledge transfer/retention program } \\
\text { Informal knowledge transfer/retention program } \\
\text { A formal knowledge transfer/retention program exists but it is not integrated into staff qualification and } \\
\text { evaluation program. } \\
\text { PB action: A formal knowledge transfer/retention program exists, as evidenced by formal mentor } \\
\text { programs or other forms of knowledge documentation efforts; the program is integrated into staff }\end{array}$ & $\begin{array}{l}1 \\
2 \\
3 \\
4\end{array}$ \\
\hline
\end{tabular}




\begin{tabular}{|c|c|c|}
\hline & qualification and evaluation programs. & \\
\hline $\begin{array}{l}\text { Country maintains accurate } \\
\text { records of all nuclear } \\
\text { exports/imports and makes } \\
\text { them available to the } \\
\text { IAEA. }\end{array}$ & $\begin{array}{l}\text { Nuclear exports/imports are state secrets } \\
\text { The State only provides information about its nuclear exports and imports upon request. } \\
\text { The State Export/Information is fully and proactively shared with the IAEA. } \\
\text { PB Action: State's nuclear suppliers and facilities share nuclear export/import information with } \\
\text { other States to ensure all sales remain dedicated to peaceful use; industry follows good corporate } \\
\text { governance and self-regulation practices. }\end{array}$ & $\begin{array}{l}1 \\
2 \\
3 \\
4\end{array}$ \\
\hline $\begin{array}{l}\text { Industry collaborates with } \\
\text { the government in sharing } \\
\text { nonproliferation } \\
\text { information and training } \\
\text { activities. }\end{array}$ & $\begin{array}{l}\text { Industry does not share information or training activities } \\
\text { Industry shares selected pieces of information } \\
\text { Industry shares all nonproliferation information but only on an ad hoc basis or upon request. } \\
\text { Performance Based Action: Industry and government have formal information sharing } \\
\text { mechanisms (Working Groups, etc.) and integrate training activities. }\end{array}$ & $\begin{array}{l}1 \\
2 \\
3 \\
4\end{array}$ \\
\hline \multicolumn{3}{|c|}{$\begin{array}{l}\text { The operator places a priority on implementing international safeguards best practices and views safeguards implementation } \\
\text { as complementary to its primary mission. }\end{array}$} \\
\hline $\begin{array}{l}\text { Provides complete and } \\
\text { accurate declarations and } \\
\text { facility attachments. }\end{array}$ & $\begin{array}{l}\text { Between } 0-49 \% \text { of the State's declarations are complete and accurate. } \\
\text { Between } 50-99 \% \text { of the State's declarations are accurate and complete. } \\
100 \% \text { of the State's declarations are complete and accurate }\end{array}$ & $\begin{array}{l}1 \\
2 \\
3\end{array}$ \\
\hline $\begin{array}{l}\text { How many cycles did it } \\
\text { take to achieve Full, Final } \\
\text { and Complete Disclosure }\end{array}$ & $\begin{array}{l}\text { Ten or more cycles were required to achieve full, final and complete disclosure. } \\
\text { Three to nine cycles were required. } \\
\text { Two or fewer cycles were required. }\end{array}$ & $\begin{array}{l}1 \\
2 \\
3\end{array}$ \\
\hline $\begin{array}{l}\text { Conducts physical } \\
\text { inventories (PI) and } \\
\text { submits MC\&A reports on } \\
\text { time. }\end{array}$ & $\begin{array}{l}0-49 \% \text { of all physical inventories are complete, accurate and delivered on time. } \\
50-99 \% \text { of all physical inventories are complete, accurate and delivered on time. } \\
100 \% \text { PIs are complete, accurate, and submitted on time. }\end{array}$ & $\begin{array}{l}1 \\
2 \\
3\end{array}$ \\
\hline $\begin{array}{l}\text { Has a personnel reliability } \\
\text { plan with clear } \\
\text { enforcement mechanisms. }\end{array}$ & $\begin{array}{l}\text { Facility has no personal reliability program } \\
\text { Some aspects of a personnel reliability program exist, but enforcement is lacking } \\
\text { Robust personnel reliability program with enforcement }\end{array}$ & $\begin{array}{l}1 \\
2 \\
3\end{array}$ \\
\hline
\end{tabular}




\begin{tabular}{|c|c|c|}
\hline $\begin{array}{l}\text { Requires the incorporation } \\
\text { of safeguards-by-design } \\
\text { when refurbishing or } \\
\text { building new facilities. }\end{array}$ & $\begin{array}{l}\text { Operators resist incorporation of safeguards-by-design } \\
\text { Operators accept incorporation of safeguards-by-design } \\
\text { Operators proactively incorporate safeguards-by-design }\end{array}$ & $\begin{array}{l}1 \\
2 \\
3\end{array}$ \\
\hline $\begin{array}{l}\text { Communicates its } \\
\text { safeguards, safety and } \\
\text { security best practices to } \\
\text { the public. }\end{array}$ & $\begin{array}{l}\text { Does not involve key stakeholders or the public in facility affairs. } \\
\text { Conducts limited outreach to key constituents/stakeholders of the facility } \\
\text { Has a formal public relations program that encourages public involvement in facility activities }\end{array}$ & $\begin{array}{l}1 \\
2 \\
3\end{array}$ \\
\hline $\begin{array}{l}\text { Maintains effective cyber } \\
\text { security measures to } \\
\text { protect sensitive } \\
\text { safeguards data. }\end{array}$ & $\begin{array}{l}\text { Does not take precautions to protect sensitive safeguards data } \\
\text { Protects sensitive safeguards data } \\
\text { Proactively seeks state-of-the-art cyber security measures to protect sensitive safeguards data }\end{array}$ & $\begin{array}{l}1 \\
2 \\
3\end{array}$ \\
\hline \multicolumn{3}{|c|}{$\begin{array}{l}\text { The country's nuclear personnel, including managers, scientists, engineers, technicians, and regulatory personnel view } \\
\text { safeguards implementation as important to them personally and complementary to their missions. }\end{array}$} \\
\hline $\begin{array}{l}\text { Students view safeguards } \\
\text { as a long-term career } \\
\text { option. }\end{array}$ & $\begin{array}{l}\text { 0-25\% of all students studying nuclear or safeguards-applicable topics }{ }^{\text {viii }} \text { apply for professional } \\
\text { safeguards positions in government, industry or IAEA. } \\
26-75 \% \text { of all students studying nuclear or safeguards-applicable topics apply for professional safeguards } \\
\text { positions in government, industry or IAEA. } \\
76-100 \% \text { of all students studying nuclear or safeguards-applicable topics apply for professional } \\
\text { safeguards positions in government, industry or IAEA. } \\
\text { PB action: Students take courses specifically to prepare them for safeguards positions. }\end{array}$ & 2 \\
\hline $\begin{array}{l}\text { If students seek training } \\
\text { abroad, they return to fill } \\
\text { safeguards positions. }\end{array}$ & $\begin{array}{l}\text { Staff personnel trained abroad do not return to the country. } \\
\text { Staff trained abroad return to country but don't fill safeguards positions } \\
\text { Staff trained abroad return to fill safeguards positions }\end{array}$ & $\begin{array}{l}1 \\
2 \\
3\end{array}$ \\
\hline $\begin{array}{l}\text { Students and nuclear } \\
\text { professionals participate in } \\
\text { professional associations, } \\
\text { such as INMM and }\end{array}$ & $\begin{array}{l}\text { Students studying nuclear issues do not participate in professional organizations. } \\
\text { Less than } 50 \% \text { of the students studying nuclear issues participate in professional organizations in order to } \\
\text { improve their performance. } \\
\text { Between } 51 \text { and } 100 \% \text { of the safeguards staff participate in professional organizations in order to }\end{array}$ & $\begin{array}{l}1 \\
2 \\
3 \\
4\end{array}$ \\
\hline
\end{tabular}




\begin{tabular}{|l|l|l|}
\hline ESARDA. & $\begin{array}{l}\text { improve their performance. } \\
\text { PB action: State seeks opportunities to host meetings and workshops supporting safeguards; } \\
\text { Students hold leadership positions in professional organizations. }\end{array}$ \\
\hline $\begin{array}{l}\text { Staff members feel they } \\
\text { have a responsibility and } \\
\text { are enabled to report } \\
\text { wrong-doing, malfeasance } \\
\text { or other problems to } \\
\text { management. }\end{array}$ & $\begin{array}{l}\text { No mechanisms exist to report wrongdoing } \\
\text { Staff personnel do not report wrong-doing for fear of retribution or other reasons. } \\
\text { Mechanisms exist and staff personnel use them, as evidenced by clear reports generated by staff. }\end{array}$ & 1 \\
& & 2 \\
\hline
\end{tabular}

\footnotetext{
'Schien, Edgar H.; Organizational Culture and Leadership. ${ }^{\text {nd }}$ Edition, Jossey-Bass; 1997

${ }^{i i}$ Frazar, Sarah, and Steve Mladineo. "Safeguards Culture: Lessons Learned.” ESARDA Bulletin. Vol 44. June 2010.

iii Nadler, David and Michael Tushman. Competing by Design: The Power of Organizational Architecture. New York. Oxford University Press. 1997. Page 34 .

${ }^{\text {iv }}$ A guide to selecting appropriate tools to improve HSE culture, Report No. 435, International Association of Oil and Gas Producers, March 2010.

${ }^{\mathrm{v}}$ Evidence of political support for the SSAC may be official advocacy for its mission and objectives, public recognition for its role in safeguards, or $\mathrm{g}$ overnment investment in SSAC staff training programs etc.

${ }^{\text {vi }}$ For example, State recognizes publically SSAC's authority to conduct national inspections but it does not designate staff or financial support for such activities

${ }^{\text {vii }}$ For purposes of this paper, we are focusing on the academic areas that are most directly applicable to safeguards: nuclear engineering, physics, accountancy, statistics, international relations and international law.
} 



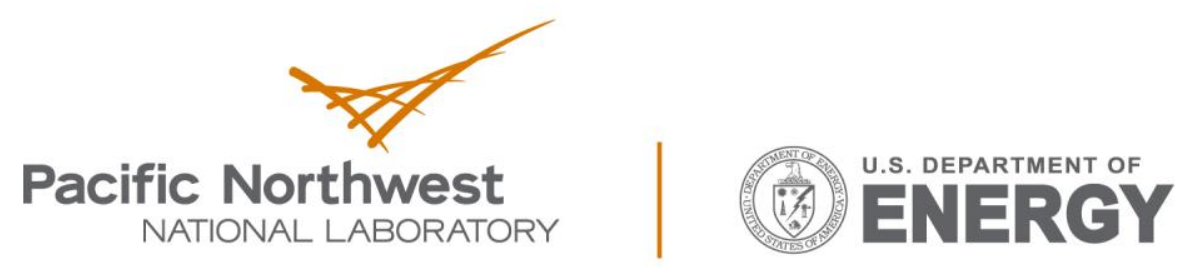

Proudly Operated by Battelle Since 1965

902 Battelle Boulevard

P.O. Box 999

Richland, WA 99352

1-888-375-PNNL (7665)

www.pnnl.gov 